\title{
Glacial lake outburst flood risk in Himachal Pradesh, India: an integrative and anticipatory approach considering current and future threats
}

\author{
S. K. Allen ${ }^{1}$ A. Linsbauer ${ }^{1,2} \cdot$ S. S. Randhawa ${ }^{3}$. \\ C. Huggel ${ }^{1}$ P. Rana $^{3} \cdot$ A. Kumari ${ }^{3}$
}

\begin{abstract}
Glacial lake outburst floods (GLOFs) are a serious and potentially increasing threat to livelihoods and infrastructure in most high-mountain regions of the world. Here, we integrate modelling approaches that capture both current and future potential for GLOF triggering, quantification of affected downstream areas, and assessment of the underlying societal vulnerability to such climate-related disasters, to implement a first-order assessment of GLOF risk across the Himalayan state of Himachal Pradesh (HP), Northern India. The assessment thereby considers both current glacial lakes and modelled future lakes that are expected to form as glaciers retreat. Current hazard, vulnerability, and exposure indices are combined to reveal several risk 'hotspots', illustrating that significant GLOF risk may in some instances occur far downstream from the glaciated headwaters where the threats originate. In particular, trans-national GLOFs originating in the upper Satluj River Basin (China) are a threat to downstream areas of eastern HP. For the future deglaciated scenario, a significant increase in GLOF hazard levels is projected across most administrative units, as lakes expand or form closer towards steep headwalls from which impacts of falling ice and rock may trigger outburst events. For example, in the central area of Kullu, a 7-fold increase in the probability of GLOF triggering and a 3-fold increase in the downstream area affected by potential GLOF paths can be anticipated, leading to an overall increase in the assigned GLOF hazard level from 'high' to 'very high'. In such instances, strengthening resilience and capacities to reduce the current GLOF risk will provide an important first step towards adapting to future challenges.
\end{abstract}

Keywords GLOF · Climate risk · Hazard · Future lakes · Himalaya

S. K. Allen

simon.allen@geo.uzh.ch

Department of Geography, University of Zurich, Zurich, Switzerland

Department of Geosciences, University of Fribourg, Fribourg, Switzerland

3 Himachal Pradesh State Centre on Climate Change, State Council for Science, Technology and Environment, Shimla, India 


\section{Introduction}

The Indian Himalayan Region (IHR) is facing important challenges in view of coping with adverse effects of climate change. Like many other mountain regions worldwide, the IHR is particularly sensitive to changes in global climate, from both a physical and societal perspective. Physically, the disappearance of mountain glaciers and expansion of large glacial lakes are amongst the most recognisable and dynamic impacts of climate warming in this environment (Bolch et al. 2012). In combination with altered stability of surrounding rock and ice walls, the potential threat from glacial lake outburst floods (GLOFs) is thus evolving over time (Kääb et al. 2005; Schaub et al. 2013; Clague and O'Connor 2014; Deline et al. 2014). With residential, tourism, and particularly hydropower infrastructure expanding higher into alpine valleys, and human demand on limited hydrological resources intensifying, there is a clear need for improved implementation of GLOF risk reduction strategies within climate adaptation planning (Khanal et al. 2015).

GLOFs refer to the sudden discharge of a water reservoir that has formed either underneath, at the side, in front, within, or on the surface of a glacier, and related dam structures can be composed of ice, moraine, or bedrock. In the Himalaya, as elsewhere in the world, considerable focus has been on flood hazard associated with the catastrophic failure of moraine-dammed lakes (Vuichard and Zimmermann 1987; Richardson and Reynolds 2000; Liu et al. 2013; Allen et al. 2015). Other high-mountain regions affected include the Andes (Lliboutry et al. 1977; Reynolds 1992; Anacona et al. 2014), North America (Clague and Evans 2000; O'Connor et al. 2001), and Europe (Haeberli 1983; Haeberli et al. 2001). Failure of moraine-dammed lakes occurs when the material strength of the dam structure is exceeded by driving forces, including the weight of the impounded water mass, shear stresses from seepage, and overtopping or additional momentum from displacement waves (Korup and Tweed 2007). In the Himalaya, displacement waves from large impacts of ice or rock are thought to have contributed to over $50 \%$ of catastrophic moraine dam failures (Richardson and Reynolds 2000; Emmer and Cochachin 2013). GLOFs characteristically transform into hyperconcentrated or debris flows following the entrainment of loose, unconsolidated para-glacial debris (e.g. Worni et al. 2012), and some of the most devastating and far-reaching $(>100 \mathrm{~km})$ impacts have involved subsequent flow transformations or chain reactions, such as damming of valleys, secondary outbursts, and debris flows (e.g. Lliboutry et al. 1977; Huggel et al. 2005). As such, approaches to glacial lake outburst hazard assessment must consider large spatial scales, not restricted by administrative or political boundaries.

Typically, glacial flood disasters or perceived threats over recent decades have involved terminal or lateral moraine dams that formed during the Little Ice Age (LIA-between the years 1400 and 1900), and lakes that have filled during the subsequent thinning and retreat of glaciers during the twentieth century (Clague and O'Connor 2014). While in general, the threat from such lakes may be diminishing over time, assuming that the most unstable lakes would already have failed, the Himalaya are noted as one area where large proglacial lakes trapped behind LIA moraines are continuing to evolve (Clague and O'Connor 2014). For such lake reservoirs developing on or at the margins of glaciers, remote sensing-based methodologies and geographic information systems (GIS) have for more than a decade proven appropriate tools for monitoring hazardous developments across large spatial scales (e.g. Huggel et al. 2002; Wessels et al. 2002). While related large-scale (state, country to trans-national) inventories of GLOF hazard have since been implemented over much of high-mountain Asia (Ives et al. 2010; Bolch et al. 2011; 
ICIMOD 2011; Wang et al. 2011; Worni et al. 2013), assessment schemes are heterogeneous and typically still require subjective case-by-case classification of potential triggering threats such as impacts from ice or rock avalanches. Furthermore, the crucial socioeconomic factors that determine the vulnerability of a given region to outburst flood events (Hegglin and Huggel 2008; Carey et al. 2012) have been rarely integrated within largescale assessment schemes (Wang et al. 2015).

In view of projected warming and continued retreat of alpine glaciers (Church et al. 2013), attention has recently shifted beyond monitoring and assessment of existing outburst threats, towards the anticipation of where new, potentially problematic lakes will form in the future. Such lakes will mostly form in depressions or overdeepenings in the exposed glacier bed (Frey et al. 2010) and will be dammed by bedrock or moraine, depending on the glacier type, erosional properties, and rate of retreat (Linsbauer et al. 2016). Typically for lakes to be impounded by large moraine dams, such as formed during the LIA, the glacier front must remain stationary for a sufficient length of time. While future lakes may create attractive landscape features, and even offer potential for hydropower generation (Haeberli and Hohmann 2008), a primary concern is the potential threat from overtopping waves generated by mass movements of ice and rock, as warming may destabilise the surrounding steep slopes (Deline et al. 2014). Therefore, methods have been recently developed in the Swiss Alps that enable not only the identification of where new lakes might form in the exposed bed topography (Linsbauer et al. 2012), but also to recognise source areas where steep rock and ice can detach and impact into glacial lakes under both current, and future conditions (Schaub et al. 2013).

Building on these recent advances, the current study therefore aims to integrate modelling of GLOF triggering potential and resulting flood paths, quantification of affected land areas, and assessment of the underlying societal vulnerability to climate-related disasters, to implement a first-order assessment of GLOF risk across the state of Himachal Pradesh, Northern India. More specifically, the primary objectives are:

1. To implement a large-scale automated GLOF risk assessment within an integrative climate risk framework that recognises both physical and socio-economic determining factors.

2. To take the assessment beyond the current situation and to provide early anticipation of future GLOF hazard as new lakes form in response to further retreat of the Himalayan glaciers.

Our study is framed by the integrative concept of climate risk, introduced by the Intergovernmental Panel on Climate Change in their Special Report on Managing the Risk of Extreme Events and Disasters (IPCC 2012), and the Fifth Assessment Report of the IPCC (2014). These reports represented important milestones marking the confluence of the fields of climate adaptation and disaster risk management, recognising that climaterelated risk results from a physical event (hazard) intercepting with an exposed and vulnerable system (e.g. community or ecosystem) (Fig. 1). The expansion of our study to consider also future threats further brings the treatment of GLOFs in line with that of other climate risks (e.g. fluvial floods or droughts) for which policymakers require and demand best available information on projected changes over the next decades to century. Such information allows often scarce adaptation resources to be prioritised towards critical regions where further scientific investigation, monitoring, and ultimately disaster risk reduction measures may be implemented.

In the subsequent sections, we first provide an overview of the study region in Northern India and introduce the baseline data sources used in this study. Methodological details and 


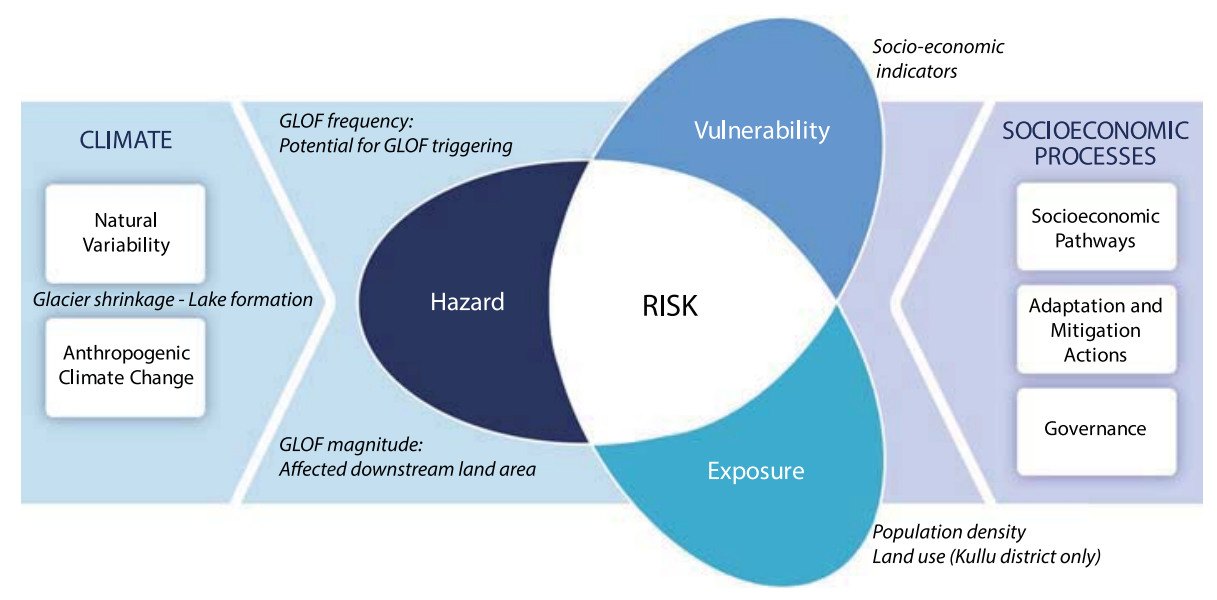

Fig. 1 Schematic overview of the IPCC concept of climate-related risk, annotated (italics) to show the relevant factors assessed in this GLOF study. Changes in both the climate system (left) and socio-economic processes (right) are drivers of hazards, exposure, and vulnerability, which in turn contribute to GLOF risk (modified from IPCC 2014)

results are then presented within two separate thematic sections: firstly, addressing the integrated assessment of current GLOF risk in Himachal Pradesh and secondly, addressing the future GLOF threat anticipated in response to ongoing retreat of the glaciers. Discussion is focussed on the perspectives and limitations of our results for adaptation planning.

\section{Study region and baseline data}

The north-western Indian Himalayan state of Himachal Pradesh (pop. ca. 6 million) has a land area of ca. $55,000 \mathrm{~km}^{2}$ (comparable in size to Switzerland). The elevation range within the state spans from 450 to $7000 \mathrm{~m}$ a.s.l, while the climate varies from tropical in the lower hills to temperate in the middle Himalayan region to cold and dry in the higher mountains. The state is characterised by a high dependency on agriculture, together with growing tourism and hydropower sectors, which together contribute towards relatively high levels of economic growth and employment, but also creates unique environmental challenges in the context of climate change (DoE S\&T 2012). The glaciated area of the state is comprised of four main hydrological basins (Fig. 2), which all ultimately flow into the Indus River. Of particular note is the large trans-national Satluj basin, which drains from glaciated headwaters in Tibet into Himachal Pradesh. An increase in mean annual air temperature of $1.6^{\circ} \mathrm{C}$ has been measured across the north-western Himalayan region during the past century, which is far in excess of mean global warming (Bhutiyani et al. 2007).

In response to atmospheric warming, glaciers across Himachal Pradesh have both fragmented and substantially reduced in size (Kulkarni and Karyakarte 2014), accompanied by significant development of glacial lakes (Randhawa et al. 2005) and an emerging GLOF threat (Government of Himachal Pradesh 2012). Baseline information on the current number of glacial lakes potentially threatening Himachal Pradesh is difficult to reconcile from previous state-wide studies, owing to differences in methodological 


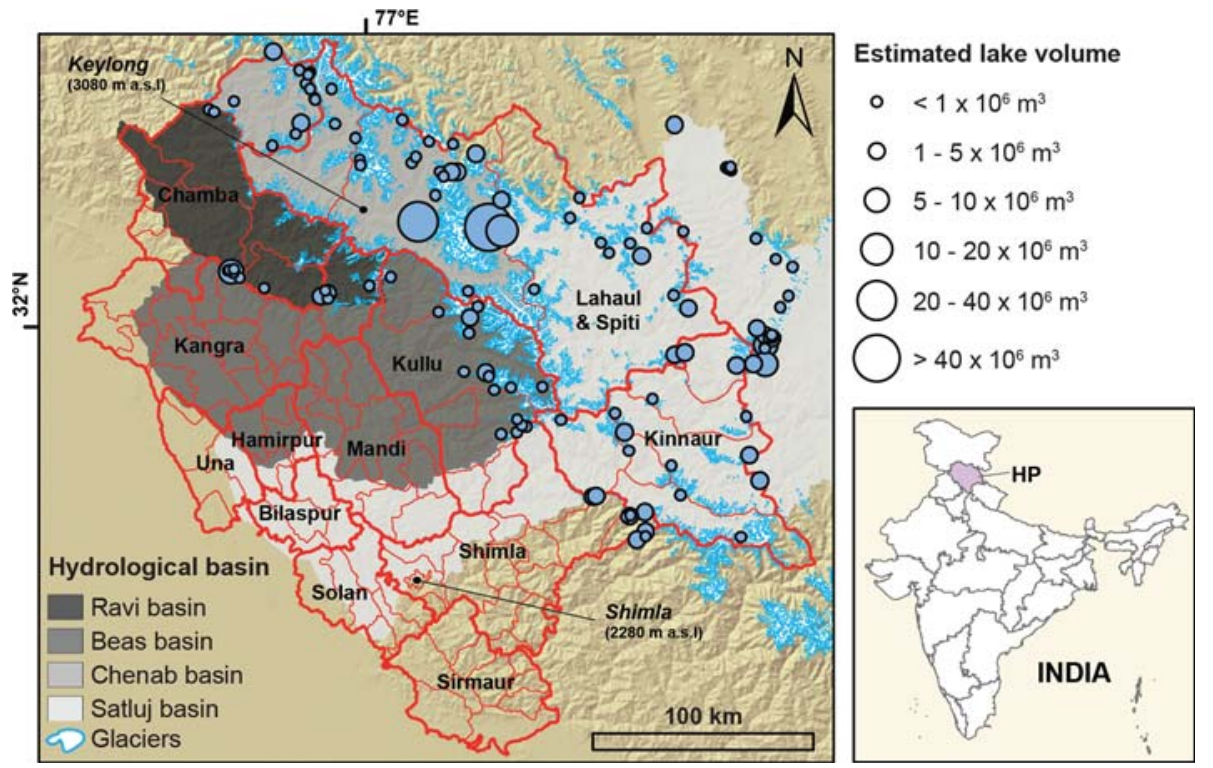

Fig. 2 Glacial lake distribution across the Indian state of Himachal Pradesh (HP). Four main hydrological basins and glaciated land area (after Frey et al. 2012) are mapped. District and Tehsil administrative boundaries are in thick/thin red lines, respectively. The volume estimate for the 120 lakes is after the empirical relationship established for Himalayan glacial lakes in Fujita et al. (2013)

approaches. Ives et al. (2010) included 156 lakes within their lake inventory for Himachal Pradesh, while Worni et al. (2013) recorded only 45 lakes focusing on water bodies larger than $0.01 \mathrm{~km}^{2}$. The most comprehensive lake inventory comes from the state government authorities, who report nearly 600 mapped lakes as of 2013 formed within the four main hydrological basins of Himachal Pradesh (HPCCC 2014). While this inventory captures lakes of all size and form, it is based on manual digitization from satellite imagery, and therefore less suited for the requirements of our integrative GLOF risk assessment, where methodologies must be repeatable, objective, and transferable across large spatial scales.

For the purpose of this study, glacial lakes across Himachal Pradesh have been remapped using latest Landsat 8 imagery from 2013 and 2014 (Level 1T), providing a robust baseline against which future changes in GLOF hazard can be assessed. Semiautomated mapping with the normalised difference water index (NDWI) was applied using the blue and near-infrared channels, which express maximum and minimum reflectance differences for glacial water and give good discrimination from ice and snow (Huggel et al. 2002). Five post-monsoon (September-October) images giving complete cloud-free coverage of the state watershed area were obtained. The inclusion of a shadow mask and image filtering (majority filter relative to 4 neighbouring pixels) reduced misclassifications and removed isolated pixels, with results validated against the manually constructed lake inventory from the state government. The final selection of glacial lakes considered only those lakes with an area $>0.01 \mathrm{~km}^{2}$ (after McKillop and Clague 2007; Worni et al. 2013), located above $3500 \mathrm{~m}$, and either dammed or fed directly by glacial processes. This final step remains somewhat subjective, but recognises that moraine-dammed lakes may be positioned well beyond the current terminus position of fast retreating glaciers. 
This study calculates and reports results for 109 Tehsils (administrative sub-divisions) across the 12 districts of Himachal Pradesh (Fig. 2). To capture those lakes that may pose a threat originating from beyond administrative boundaries, we considered the watershed area up to $50 \mathrm{~km}$ upstream of each Tehsil. The importance of such trans-boundary events is highlighted by the 2005 outburst of the landslide formed Paree Chu Lake in China, which originated ca. $35 \mathrm{~km}$ upstream of the heavily affected Himachal Pradesh District of Kinnaur (Gupta and Sah 2008; Ruiz-Villanueva et al. 2016). Although GLOFs can travel exceptional distances $(>100 \mathrm{~km}), 50 \mathrm{~km}$ provides here a reasonable extension given that flood hydrographs tend to attenuate rapidly and thereby damage potential reduces as flows propagate downstream (Worni et al. 2014). In total, 120 glacial lakes were identified within the state watershed area, including lakes within the immediate upstream area of the Satluj basin in neighbouring China (Fig. 2). The total volume of water contained in these lakes is estimated in the order of 115-230 million $\mathrm{m}^{3}$ based on empirical relationships linking mean lake depth with lake area (Huggel et al. 2002; Fujita et al. 2013). The rapidly expanding Gopeng Garth (20-35 million $\left.\mathrm{m}^{3}\right)$ and the neighbouring Chandra Taal (40-65 million $\mathrm{m}^{3}$ ), located in Chenab basin, Lahaul, and Spiti, are currently the two largest glacial lakes in Himachal Pradesh (Fig. 2).

In Sects. 3 and 4, elevation and topographic input is taken from version 2 of the $\sim 30 \mathrm{~m}$ grid resolution global digital elevation model (GDEM2) of the Advanced Spaceborne Thermal Emission and Reflection Radiometer (ASTER), and current glacial extents are from Frey et al. (2012). Socio-economic indicators and population data used in the GLOF risk assessment are from Census India 2011 (www.censusindia.gov.in).

\section{Integrated assessment of current risk}

Following the IPCC concept of climate risk, our integrated assessment of GLOF risk $(R)$ across the Tehsils of Himachal Pradesh (HP) is calculated as the consequence of the physical hazard $(H)$, intersecting with vulnerable $(V)$ and exposed people $(E)$ :

$$
R=H \cdot V \cdot E
$$

For each of these three components (hazard, exposure, and vulnerability) a standardised index is established with unitless values ranging from 1 (low) to 10 (high), ensuring all components contribute an equal weighting to the final risk index.

\subsection{Hazard index}

In this study, we assess the GLOF hazard for each Tehsil in terms of the probability $(P)$ of GLOF triggering (based on modelled predisposition of each lake to triggering impacts from falling ice or rock), and in terms of the potential GLOF magnitude (M) (based on the modelled affected downstream land area):

$$
H=P \cdot M
$$

where both input values and the final hazard index are standardised (based on the same standardisation method as used in Eq. 3).

As indicated by Richardson and Reynolds (2000), mass movements of ice and rock are the most common trigger of recorded GLOF events in the Himalaya, and the frequency of such triggering may be directly influenced by warming of the climate system (Deline et al. 
2014). The GIS-based approach we used to determine the potential probability of GLOF triggering from any given lake is based on the concept of topographic potential (Romstad et al. 2009) which encompasses (a) the potential for rock or ice to detach (parameterised by slope angle) and (b) the potential for the resulting rock and/or ice avalanche to reach a glacial lake (parameterised by the overall trajectory slope or angle of reach) (Fig. 3). This concept was recently integrated within a comprehensive risk analyses of current and future (deglaciated) conditions in the Swiss Alps (see Schaub 2015 for a full description). For implementation within HP, we do not distinguish between whether the slope is bedrock or ice-covered, and assume an impact into a lake is possible from any slope $>30^{\circ}$ (cf. Allen et al. 2011; Fischer et al. 2012), where the overall slope trajectory is $>14^{\circ}$ (cf. Noetzli et al. 2003; Romstad et al. 2009). These conservative values are based on ice and/or rock avalanches reported within an extensive global catalogue of events contained in the cited literature, although mass movements from more gentle slopes and obtaining larger run-out distances are possible in exceptional cases. The combined area within each lake watershed fulfilling these two criteria is referred to as the lake impact predisposition area. The total lake impact predisposition area is summed and normalised as a percentage of the overall watershed area of each Tehsil.

The maximum affected downstream area (potential magnitude) for any flood event is determined, based on so-called worst-case scenario modelling. For this purpose, we use the modified single-flow model (MSF) — a simple GIS-based hydrological flow routing algorithm that calculates the flow direction from one DEM pixel to another according to the steepest downward gradient between each pixel and its eight neighbours (after O'Callaghan 1984), modified to allow flow spreading of up to $45^{\circ}$ from the main flow direction (see Huggel et al. 2003 for a full description). The maximum downstream travel distance for each GLOF path is determined using an empirically derived worst-case scenario defined by the overall trajectory slope to the source lake, with values as low as $5 \%\left(3^{\circ}\right.$ angle of reach) considered appropriate for highly mobile sediment-laden events (Huggel et al. 2004). Beyond these worst-case run-out distances, no severe damages can be expected. The total land area affected by GLOF paths is summed and normalised as a percentage of the overall Tehsil land area.

The final hazard index values were ranked, and the Tehsils classified within 10 evenly distributed classes (Fig. 4a). Overall, the greatest GLOF hazard is seen across the heavily glaciated Tehsils of Lahual (L), Udaipur (U), and Pangi (P) in the northern HP Districts of

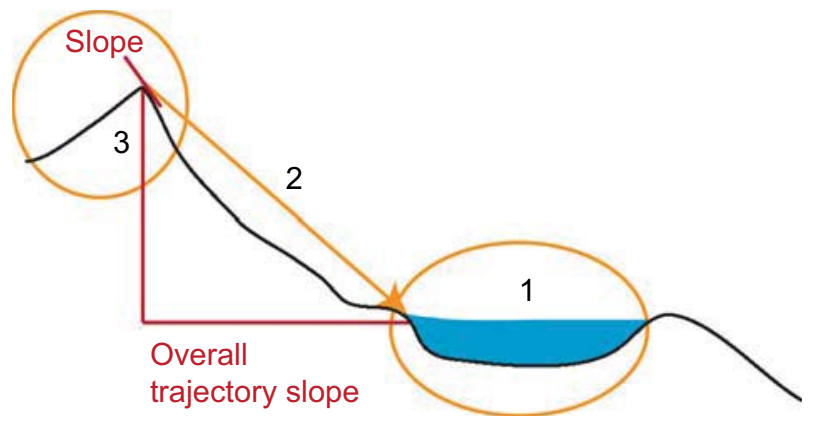

Fig. 3 Schematic sketch summarizing the concept of topographic potential used to determine the predisposition of a glacial lake to mass movement impacts of rock and ice. (1) A glacial lake has to be situated within (2) the attainable run-out distance (based on the overall trajectory slope or angle of reach) from (3) potentially unstable steep rock and ice (based on slope angle). Figure modified from Schaub (2015) 

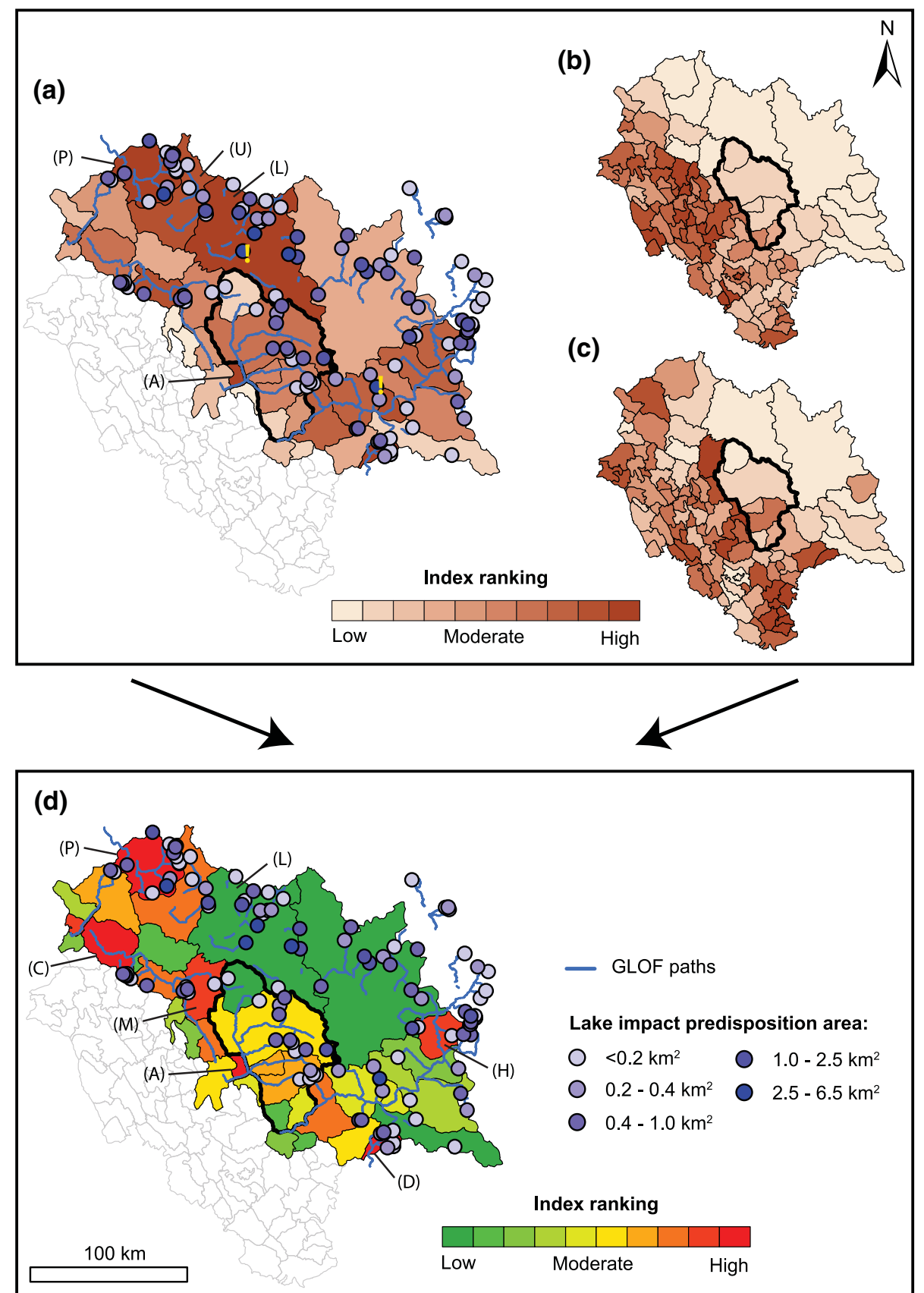

Fig. 4 GIS-based assessment of a GLOF hazard, $\mathbf{b}$ exposure and $\mathbf{c}$ vulnerability, integrated to give a final evaluation of $\mathbf{d}$ GLOF risk across the Tehsils of Himachal Pradesh. Tehsils positioned beyond the modelled worst-case maximum reach of any GLOF paths are assigned zero hazard or risk (no colour). The final index values for each component are ranked and displayed within evenly distributed classes. Identified Tehsils and their abbreviations are referred to in the text 
Lahaul and Spiti, and Chamba. Here, many glacial lakes are evident, and a high proportion of these lakes are surrounded by steep high-mountain flanks, giving rise to large impact predisposition areas from which mass movements of ice and rock may trigger outburst floods. The two lakes identified as having the highest potential for impacts from rock and ice were similarly assessed as 'critical' in the earlier study of Worni et al. (2013), where experts assessed a smaller number of lakes using high-resolution imagery. Focussing on the central District of Kullu, far-reaching GLOF events are evident, with many paths converging within the Beas valley to result in a notable area of high hazard in the adjacent downstream District of Mandi, Tehsil of Aut (A).

\subsection{Vulnerability and exposure indices}

Vulnerability is defined by the IPCC (2014) as the propensity or predisposition to be adversely affected. Vulnerability is thus determined primarily by the social, cultural, political, and institutional characteristics that influence a system's sensitivity, and capacity to anticipate, respond to, and recover from the adverse effects of climate change. A key distinction from earlier vulnerability assessment frameworks (e.g. as used in the IPCC Fourth Assessment Report), is that exposure is considered independently from vulnerability, recognising that a community may be exposed to a climate-related hazard, but not vulnerable (for example, if there are sufficient resources to protect a community living on a floodplain). To characterise vulnerability, an index is typically derived from a combination of quantifiable indicators assumed to represent the main components of vulnerability. While there are ongoing scientific debates on how best to quantify vulnerability, and which indicators should be included (Birkmann 2014), the social vulnerability index has emerged as a most widely accepted and implemented approach (e.g. Cutter et al. 2003; Cutter and Finch 2008; Chen et al. 2013). Related indexes typically draw on Census data, which provides regular, transparent, homogeneous sampling of socio-economic conditions at the national scale.

We broadly followed the approach of the social vulnerability index and used Census India data from 2011 to quantify 18 indicators representing the socio-economic components of vulnerability across all Tehsils of HP (Table 1). The selection of indicators draws upon our knowledge of the local communities and their livelihoods, with emphasis given to those factors that will determine an individual's ability to prepare, respond, and recover from climate-related impacts such as a GLOF. Some indicators capture multiple underlying factors. For example, we consider the female population in HP more vulnerable to climaterelated disasters due to their overrepresentation in climate-sensitive agricultural activities, reduced access to alternative forms of income, reduced mobility owing to household and family burdens, and lower literacy rates.

For each indicator $(I)$, Tehsil values $\left(I_{\mathrm{t}}\right)$ were standardised $\left(I_{\text {std }}\right)$ to values in a common range of 1 (indicating low vulnerability) to 10 (indicating high vulnerability) using the formula:

$$
I_{\text {std }}=\frac{1+\left(I_{\mathrm{t}}-I_{\min }\right)(10-1)}{\left(I_{\max }-I_{\min }\right)}
$$

in the case of high values indicating higher vulnerability (positive dependency) or:

$$
I_{\text {std }}=\frac{1+\left(I_{\max }-I_{\mathrm{t}}\right)(10-1)}{\left(I_{\max }-I_{\min }\right)}
$$

in the case of high values indicating reduced vulnerability (negative dependency). 
Table 1 Indicators used in the vulnerability assessment for Himachal Pradesh, India

\begin{tabular}{lll}
\hline Indicator & Components represented & Dependency $^{\text {a }}$ \\
\hline Female population & Sensitivity, capacity to prepare, respond and recover & + \\
Population $<6$ years of age & Sensitivity, capacity to prepare, respond and recover & + \\
Population $>60$ years of age & Sensitivity, capacity to prepare, respond and recover & + \\
Literacy rate & Capacity to prepare, respond and recover & - \\
Unemployment & Capacity to prepare, respond and recover & + \\
Employment in farming & Sensitivity, capacity to recover & + \\
Disabled population & Sensitivity, capacity to prepare, respond and recover & + \\
Home renters & Capacity to recover & + \\
Derelict houses & Sensitivity, capacity to respond and recover & + \\
Water availability & Capacity to prepare and respond & - \\
Medical facilities & Capacity to prepare and respond & - \\
Education facilities & Capacity to prepare, respond and recover & - \\
Banking services & Capacity to prepare and recover & - \\
Access to radio & Capacity to prepare and respond & - \\
Access to TV & Capacity to prepare and respond & - \\
Access to internet & Capacity to prepare and respond & - \\
Access to mobile & Capacity to prepare and respond & - \\
Access to vehicle & Capacity to prepare, respond, and recover & -
\end{tabular}

The main components of vulnerability represented by each indicator are listed, and the dependency of the relationship with vulnerability is given. For further description on the various indicators and the vulnerability components they represent, see Cutter et al. (2003) and references cited therein

a A positive (+) dependency means that an increase in the measured variable indicates an increase in vulnerability. A negative (-) dependency means that an increase in the measured variable indicates a decrease in vulnerability

We gave equal weighting to all indicators, such that the final vulnerability index (VI) for each Tehsil was simply calculated as the average across all standardised scores:

$$
\mathrm{VI}=\frac{\sum I_{\mathrm{std}}}{N}
$$

Exposure marks the presence of people, livelihoods, environmental services, infrastructure, and other resources that could be adversely affected by a potential hazard. In our first-order assessment of GLOF risk, we used population density at the Tehsil level to derive a standardised proxy index of exposure. We assume therefore that higher population densities at the Tehsil scale indicate an increased number of people living or working in flood-prone river valleys, a reasonable assumption given the cultural, hydrological, ecological, and economic importance of the rivers and their surrounding fertile floodplains, where major habitations are frequently located. For Kullu District, land cover data were generated (agricultural land, roads/tracks, and habitations) and is used to further analyse the patterns of exposure in flood-affected areas in this district only.

Exposure and vulnerability patterns broadly correlate across HP, with generally lower vulnerability and lower exposure evident towards the mountainous regions in the north, although notable pockets of higher vulnerability are evident (Fig. $4 b, c)$. This pattern of 
vulnerability is generally consistent with previous assessments (DoE S\&T 2012), despite differences in concepts and methodological approach used.

\subsection{Synthesis of current GLOF risk}

When the indices for GLOF hazard, vulnerability, and exposure are combined, several 'hotspots' of GLOF risk become evident across the state of HP, and it is clear that areas of significant risk may in some instances be located far downstream from where the threats originate (Fig. 4d). The most widespread area of GLOF risk is in the north-western corner of HP, and particularly within the Tehsils of Pangi and Chamba (Chamba District). Whereas the mountainous Tehsil of Pangi (mean elevation $4100 \mathrm{~m}$ a.s.l) is directly threatened from the many lakes within its administrative boundaries, Chamba (mean elevation $2200 \mathrm{~m}$ a.s.l) is more heavily populated (and therefore more exposed), and the threat comes from potentially far-reaching GLOF events originating further upstream. In eastern HP, the Tehsil of Hangrang (Kinnaur District) has higher levels of vulnerability than surrounding areas and is threatened by numerous potential GLOFs originating in both Indian and Chinese sectors of the upper Satluj river basin. Trans-national outburst floods from landslide-dammed lakes have caused significant devastation in this region previously (Gupta and Sah 2008; Ruiz-Villanueva et al. 2016). In south-eastern HP, Dodra Kwar (Shimla District) is a small, sparsely populated, yet highly vulnerable Tehsil threatened by numerous lakes. In addition, high vulnerability and/or exposure also contribute to overall significant GLOF risk in Multhan (Kangra District) and Aut (Mandi District). The contrast between hazard and risk is most obvious for the Northern Tehsil of Lahaul (Lahaul and Spiti District). Despite there being many potentially threatening glacial lakes within this Tehsil (and corresponding high hazard), GLOF risk is considered low owing to the very low population density, and low levels of societal vulnerability (Fig. 4).

\section{Future GLOF threat}

To extend the GLOF risk assessment for HP beyond the current situation, we provide early anticipation of where new lakes will develop as glaciers continue to retreat over the $21 \mathrm{st}$ century and assess the related implications for GLOF hazard. It is beyond the scope of this study to consider future scenarios of socio-economic and demographic change, as would be required to complete a comprehensive future risk assessment.

\subsection{Future lake development}

The erosive power of glaciers can form large depressions at the bed and when such overdeepened parts are exposed due to glacier retreat and filled with water, rather than sediments, new lakes can form (Clague and Evans 1994). Hence, by detecting overdeepenings in the glacier bed, sites of potential future lake formation and possible expansion of existing lakes can be identified. The GIS-based model GlabTop was developed for estimating ice thickness distribution and bed topography across the Swiss Alps (Linsbauer et al. 2012; Paul and Linsbauer 2012), and an improved version (GlabTop2) has subsequently been applied for large-scale modelling in the Himalaya (Frey et al. 2014; Linsbauer et al. 2016). GlabTop2 was implemented in the current study, requiring only a surface DEM and glacial outlines as input (see Sect. 2 for data sources). The modelled ice 
thickness distribution is subtracted from a surface DEM to obtain the bed topography, i.e. a DEM without glaciers, from which overdeepenings in the glacier bed can be detected and analysed (see, Linsbauer et al. 2012, 2016) (Fig. 5).
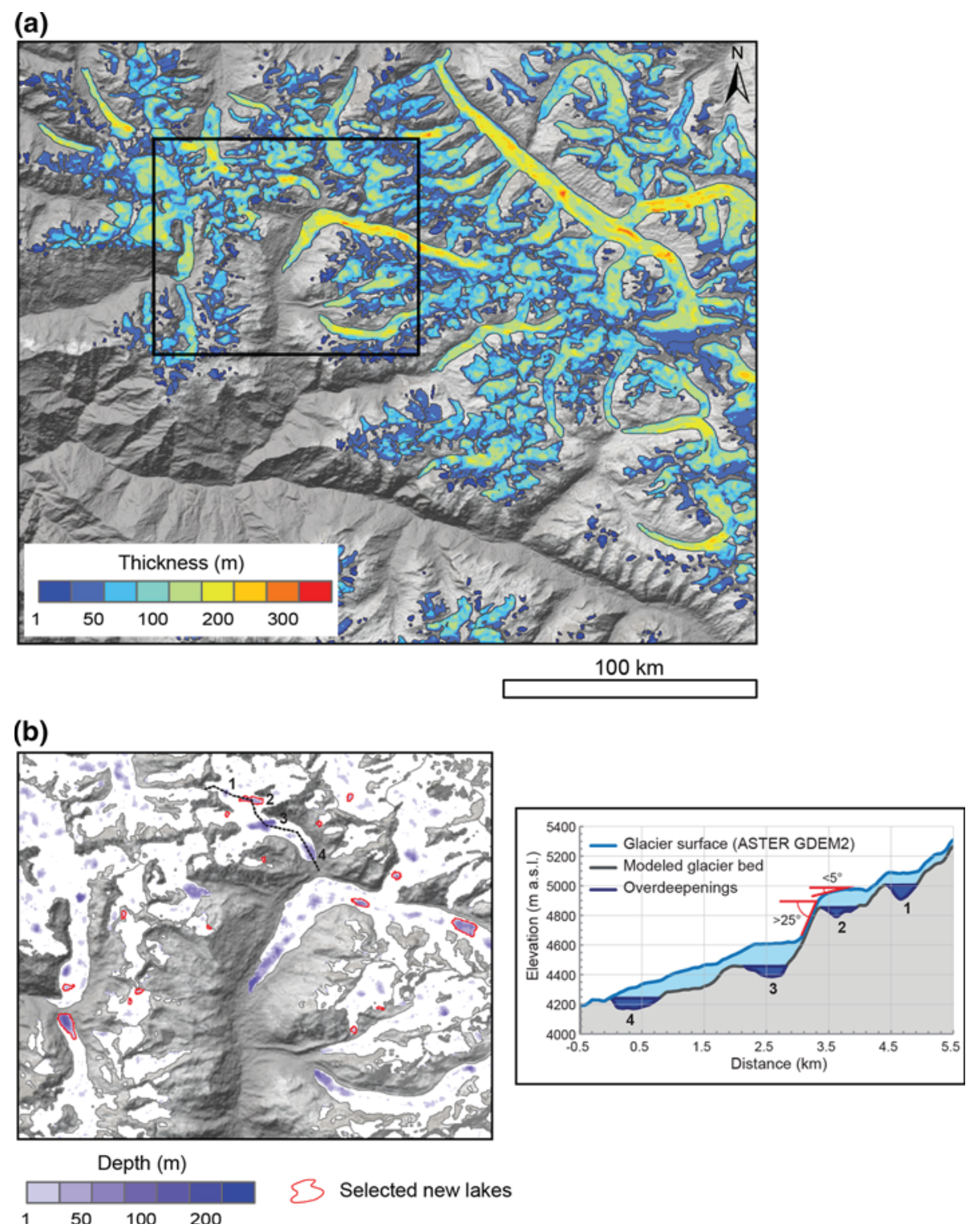

Fig. 5 Modelled $\mathbf{a}$ ice thicknesses and $\mathbf{b}$ overdeepenings in the glacier bed topography for a glaciated area above the Parvati Valley, Kullu District, HP. Final selected overdeepenings where new lakes are considered most likely to develop within the exposed bed topography are indicated. A longitudinal profile is provided along one glacier illustrating the overdeepenings in the bed. Based on the sudden steepening of topography, overdeepening 2 is selected as a most likely location where a new lake will form 
In total, more than 4000 overdeepenings $\left(>0.01 \mathrm{~km}^{2}\right)$ are modelled beneath the glaciers of HP (Table 1). In order to refine the focus to those situations where potential lakes will first develop over the coming decades, only those lakes below the current mean elevation of the glacier, i.e. approximating the glacier ablation area (after Braithwaite and Raper 2009), were selected for further analyses. Exact timescales for lake formation are highly uncertain, but Cogley (2011) demonstrated that if recent rates of glacial retreat across the Himalaya-Karakoram region were to remain constant, or continue accelerating, total mass would decrease by around 50 to $75 \%$ by the year 2035 (relative to 1985). Such retreat would be sufficient to expose the bed topography within the current ablation areas of most glaciers. In a final selection step, a key topographic criterion for lake formation established by Frey et al. (2010) was automated to identify only those overdeepenings located above a sudden steepening in topography. This steepening was approximated by mean slope values $>25^{\circ}$ within a zone $300 \mathrm{~m}$ immediately below the overdeepening and identifies situations where there is a higher likelihood of a thick overdeepened part of the glacier occurring, with steeper, thinner ice below (see overdeepening 2 in Fig. $5 \mathrm{~b}$ ). This value of $25^{\circ}$ was found to best capture the classical situation described by Frey et al. (2010), where following the retreat of ice over a steep break in topography, we can be most confident that a future lake will form behind a steep dam. From this selection process, 279 potential new lakes were identified across the state of HP (see Table 2, and examples shown in Fig. 5) and used for subsequent analyses of future GLOF hazard. In addition overdeepenings intercepting with current proglacial lakes were included, as these provide an indication of the maximum future extent of these lakes (e.g. Gopeng Garth in Fig. 8).

The selected new lakes represent less than $10 \%$ of all modelled overdeepenings in the glacier bed topography and thus should be considered a conservative lower estimate for the actual number of glacial lakes that may develop in the future. Maximum lake depths exceed $100 \mathrm{~m}$, with the modelled mean depth across all 279 lakes being $15 \mathrm{~m}$. The largest new lake has a modelled volume of 30 million $\mathrm{m}^{3}$, while the mean volume of all new lakes is 1.1 million $\mathrm{m}^{3}$. Although the greatest numbers of potential new lakes are identified in the Chenab and Satluj basins, the total volume of water stored in the potential lakes is largest in the Beas basin, owing to the significantly larger mean lake volumes modelled there (Table 2).

Table 2 Selection of potential new lakes within modelled overdeepenings in the glacier bed, listed for four main hydrological basins (see Fig. 1), and for the entire state watershed area of Himachal Pradesh

\begin{tabular}{|c|c|c|c|c|}
\hline \multirow{2}{*}{$\begin{array}{l}\text { Hydrological } \\
\text { basin }\end{array}$} & \multicolumn{4}{|c|}{ Selection steps to identify new lakes based on modelled overdeepenings } \\
\hline & $\begin{array}{l}\text { 1) } \\
>0.01 \mathrm{~km}^{2}\end{array}$ & $\begin{array}{l}\text { 2) Below mean } \\
\text { elevation of the } \\
\text { glacier }\end{array}$ & $\begin{array}{l}\text { 3) Above a } \\
\text { topographic } \\
\text { steepening }\end{array}$ & $\begin{array}{l}\text { Total (mean) volume of selected } \\
\text { potential new lakes }\left(\mathrm{m}^{3} \times 10^{6}\right)\end{array}$ \\
\hline Ravi & 163 & 125 & 15 & $18.7(1.2)$ \\
\hline Beas & 601 & 453 & 63 & $112.5(1.8)$ \\
\hline Chenab & 1866 & 1566 & 98 & $93.9(1.0)$ \\
\hline Satluj & 1262 & 1120 & 76 & $52.7(0.7)$ \\
\hline State-wide & 4253 & 3572 & 279 & $313.9(1.1)$ \\
\hline
\end{tabular}

The number of potential lakes remaining after each sequential selection step is indicated. The total and mean modelled (GlabTop2) volume of the final lake selection is given 


\begin{tabular}{|c|c|c|c|c|c|c|c|}
\hline \multirow{5}{*}{ 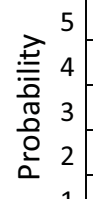 } & $>0.25 \%$ & 3 & 4 & 4 & 5 & 5 & \multirow{2}{*}{ Very high } \\
\hline & $0.13-0.25 \%$ & 3 & 3 & 4 & 4 & 5 & \\
\hline & $0.07-0.13 \%$ & 2 & 3 & 3 & 4 & 4 & High \\
\hline & $0.03-0.07 \%$ & 2 & 2 & 3 & 3 & 4 & Moderate \\
\hline & $<0.03 \%$ & 1 & 2 & 2 & 3 & 3 & \multirow{3}{*}{$\begin{array}{l}\text { Very low } \\
\text { Low }\end{array}$} \\
\hline \multirow{2}{*}{1} & & $>0.23 \%$ & $0.23-0.54 \%$ & $0.54-0.97 \%$ & $0.97-1.50 \%$ & $>1.50 \%$ & \\
\hline & & 1 & 2 & $\begin{array}{c}3 \\
\text { Magnit }\end{array}$ & de & 5 & \\
\hline
\end{tabular}

Fig. 6 GLOF hazard classification scheme where the hazard level is determined on the basis of potential probability of GLOF triggering (lake impact predisposition area expressed as a percentage of the overall watershed area of each Tehsil), and GLOF magnitude (GLOF-affected land area expressed as a percentage of the total land area within each Tehsil). The hazard level is the mean of the probability and magnitude scores (rounded)

\subsection{Change in GLOF hazard}

To demonstrate the influence that future lake development will have on GLOF hazard, Tehsil-scale analyses of lake impact predisposition area and GLOF-affected land area (see Sect. 3.1) are repeated for future deglaciated conditions, i.e. where 279 new lakes may have potentially formed, and many other proglacial lakes have significantly expanded. For the integrated risk assessment (Sect. 3), a standardised index approach was used, applying values from 1 to 10 . This was required to ensure an even weighting with vulnerability and exposure indexes. For a comparison between current and future conditions, however, this approach was less suited because in both current and future situations, the maximum values would be standardised to fill the same range, inhibiting a direct comparison. Instead, a 5-category matrix-based hazard classification scheme is used (Fig. 6), allowing the comparison between current and future conditions. In this classification scheme, the probability and magnitude class divisions are statistically defined (natural jenks) based on the current conditions and subsequently applied also for the future conditions.

The results clearly demonstrate a significant future increase in relative GLOF hazard levels across most Districts and Tehsils, as the overall potential for GLOFs being triggered from mass movements of ice and rock increases, and as new GLOF paths affect additional land areas (Fig. 7). However, future GLOF paths remain confined to those same administration units currently threatened. Particularly, in eastern HP (Kinnaur District), very high hazard levels may eventuate within Tehsils that currently only face low to moderate threats. Across most Tehsils, the simulated increase in lake impact predisposition area (probability of GLOF triggering) is of an order of magnitude larger than the simulated increase in GLOF-affected area, as paths from newly formed glacial lakes generally converge downstream within existing potential flood channels. In the Tehsil of Kullu (K) for example, modelling demonstrates a 7-fold increase in the probability of GLOF triggering and a 3 -fold increase in the area affected by potential GLOF paths, leading to an overall increase in GLOF hazard rating from 'high' to 'very high'.

The expected large increase in GLOF frequency is based on the simple, yet robust concept of topographic potential (Sect. 3.1). As demonstrated for Gopeng Garth, in northern HP, the lake impact predisposition area from which mass movements of ice and rock can detach from will increase over time, not only as existing lakes expand higher into the surrounding basins, but also as new lakes develop (Fig. 8). For Gopeng Garth, steep 


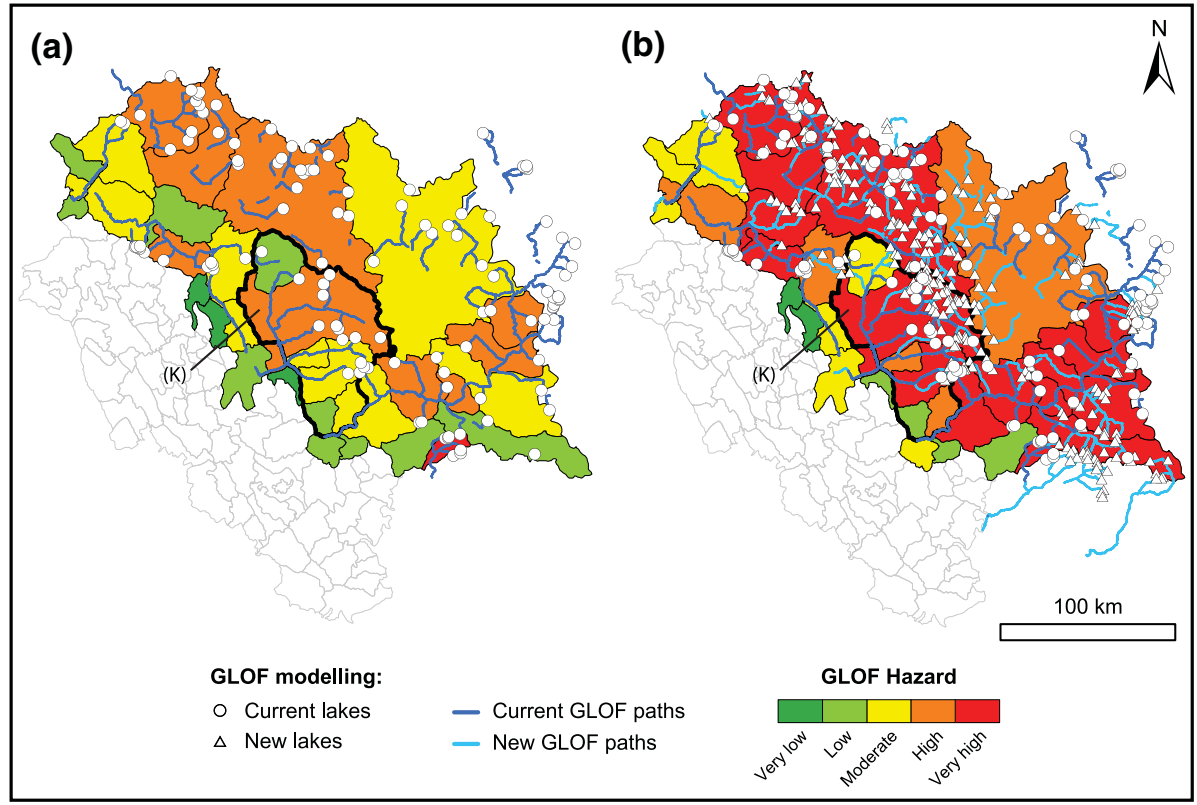

Fig. 7 a Current and $\mathbf{b}$ future GLOF hazard across the Tehsils of Himachal Pradesh, considering worst-case scenario modelling of potential GLOF paths. The hazard classification scheme is given in Fig. 6. The expansion of existing lakes and formation of new lakes will increase the potential for mass movements of ice or rock to trigger GLOF events, and new GLOF paths will increase the downstream potentially affected land area. The Tehsil of Kullu (K), within the central District of Kullu is identified

$\left(>30^{\circ}\right)$ ice or rock slopes located within a $>14^{\circ}$ overall slope trajectory to the current lake are mostly limited to the terrain immediately adjacent to the lake. However, as the lake expands in the future to fill the modelled overdeepened area, the potential source area for rock or ice avalanches that may reach the lake significantly increases to include much of the surrounding basin, whereas the current lake is mostly susceptible to impacts striking perpendicular to the lake orientation, future impacts may enter the lake from an angle which directs full wave energy towards the lake outlet, further increasing the potential for catastrophic breaching.

\section{Discussion}

Emphasis in this study has been given to the changing potential for GLOFs to be triggered by mass movements of ice or rock, and a first large-scale approach to assessing the related hazard has been presented. For moraine-dammed lakes, further parameters that may be integrated within a more complete large-scale assessment of dam stability and current GLOF hazard include dam geometry and freeboard height (Huggel et al. 2004), the steepness of the lake front area (Fujita et al. 2013), growth of the lake and associated glacier retreat (Bolch et al. 2008), vegetation coverage in the dam area (Allen et al. 2009), and permafrost conditions (Bolch et al. 2011). However, some of these factors become highly uncertain, or, for dam characteristics, impossible to establish for the modelled future lakes. The 2013 Kedarnath (state of Uttarakhand) flood disaster that killed several 


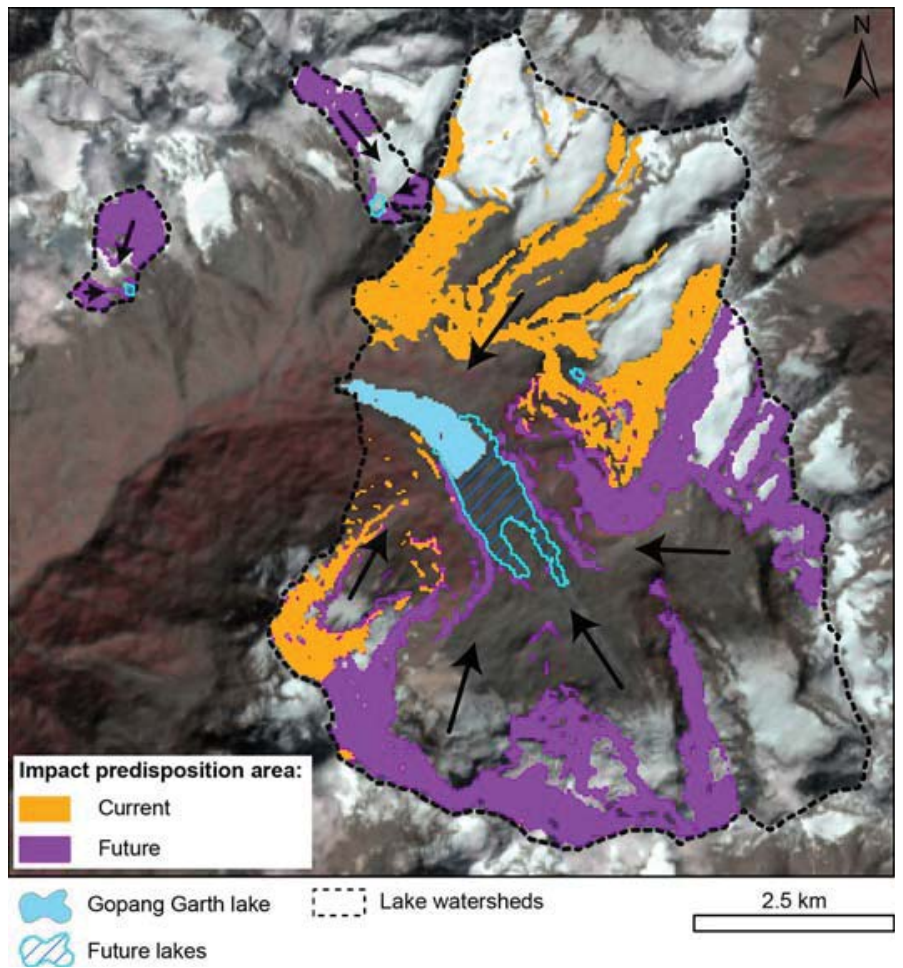

Fig. 8 Area around Gopeng Garth in the District of Lahaul and Spiti, northern Himachal Pradesh, showing potential source areas of steep $\left(>30^{\circ}\right)$ ice and rock located within an overall trajectory slope of $>14^{\circ}$ from current and future glacial lakes. Arrows indicated the general direction from which mass movements of ice or rock may impact the lakes

thousands of people has highlighted that extreme hydrometeorological conditions can trigger catastrophic GLOFs (Singh et al. 2014; Allen et al. 2015), yet knowledge on how such conditions may change in the future is limited by uncertainty in regional climate projections. Baseline information on permafrost distribution in the Kullu District has recently been established (Allen et al. 2016), but ground temperature measurements and further field validation is required before the implications of thawing permafrost on GLOF stability can be reasonably quantified and integrated into a hazard assessment. Furthermore, we have focussed here only on new threats originating from lakes that may form within the current ablation areas of the glaciers, assuming that over the coming decades, threats in this zone will emerge first and therefore be of most relevance for immediate adaptation planning. Constraining the temporal evolution of future lake development should be a priority for ongoing research. Within highly erosive environments, some overdeepenings in the bed topography will fill with sediment, and not water, particularly where deglaciation is most rapid and where permafrost is thawing in surrounding slopes (Linsbauer et al. 2016).

Nonetheless, the results of our study deliver two levels of information that provide now a firm scientific basis for adaptation planning. Firstly, a standardised risk index (Sect. 3) identifies those areas where communities are most exposed and vulnerable to GLOFs under current glacial conditions. Secondly, focusing only on the physical threat, classified hazard 
maps are produced for current and future (deglaciated) conditions (Sect. 4), providing early anticipation of where new threats are likely to emerge over the next decades.

The GLOF risk index can direct local authorities to those Tehsils where adaptation resources may be best prioritised, but provides a coarse indication only and does not imply a homogeneous level of risk will be experienced across a given Tehsil. Loss and damage from GLOFs will rather be concentrated along the fluvial terraces and floodplain areas, which may in some instances be far downstream from source lakes. Particularly, where GLOF paths converge within main river valleys, communities and livelihoods face significant risk, as it is precisely in such areas where economically significant agricultural activities are concentrated, and vital transportation links can be exposed (Fig. 9). For the communities living in such areas, monsoon-related flooding and cloudburst-triggered flash floods are often a familiar and reoccurring threat, but awareness of GLOFs, and the potential emerging threat from climate-driven changes occurring high in the glaciated watersheds is lacking. This study has demonstrated that the formation of new lakes over subsequent decades will primarily lead to an increase in the potential frequency of GLOFs, as larger and more numerous lakes mean that the likelihood of falling ice or rock avalanches entering into a lake and causing a catastrophic overtopping wave increases. The downstream land area threatened by GLOFs will also increase, but to a lesser degree, as paths from newly formed lakes will for the most part flow along stream channels within the potential flood path of already existing lakes. Within these stream channels, larger peak discharges and maximum flow heights may be anticipated for the future as upstream lake volumes expand, increasing the potential for land inundation and damages, but more detailed projections requiring physically based dynamic modelling of individual outburst events are outside the scope of this study.

Where mapped land cover data is available, an improved characterisation of GLOF exposure, and thereby an improved basis for adaptation planning under current and future conditions, is possible (Fig. 10). In Kullu District, if disaster risk reduction is the intended priority, then attention should be towards those Tehsils where current risk levels are highest and where habitations are directly threatened by GLOF activity (i.e. Tehsils of Banjar, Kullu, and Sainj). On the other hand, if national transportation routes are interrupted or agricultural productivity compromised, risks will be far-reaching and may not be adequately captured in the index approach applied herein. Particularly, in view of anticipated emerging threats, Manali could be considered a focus area for adaptation measures that protect the long-term sustainability of nationally significant road infrastructure, and agricultural areas, despite only low levels of current societal risk assessed for this Tehsil (Fig. 10).

Approaches implemented in this study identify three situations and thereby opportunities for implementation of adaptation strategies. Firstly, locations currently threatened by GLOFs but where no emerging new threats are anticipated (1 in Fig. 9b), secondly, locations where entirely new threats are anticipated to emerge ( 2 in Fig. 9b), and thirdly, locations currently threatened by GLOFs where the threat is anticipated to increase in response to continued upstream deglaciation ( 3 in Fig. 9b). In those valleys or locations where potential GLOFs from new lakes will flow primarily along existing flood paths, any adaptation measures implemented now will offer dual benefits-reducing not only the current GLOF risk, but also responding to the emerging risk anticipated for the coming decades. Such adaptation strategies can be considered as 'low-regret' measures, i.e. responses that offer immediate benefits to the communities now while also offering benefits over a range of possible future scenarios (Lal et al. 2012). These might include costeffective soft adaptation measures such as raising local awareness and developing disaster 


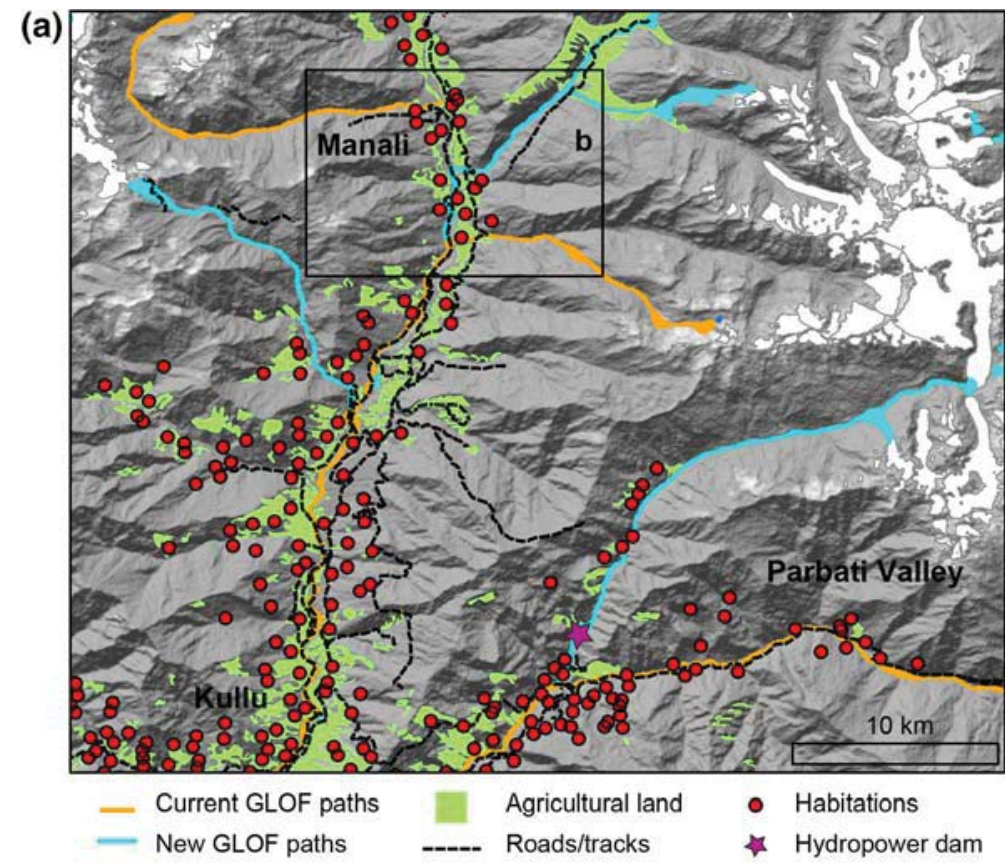

(b)

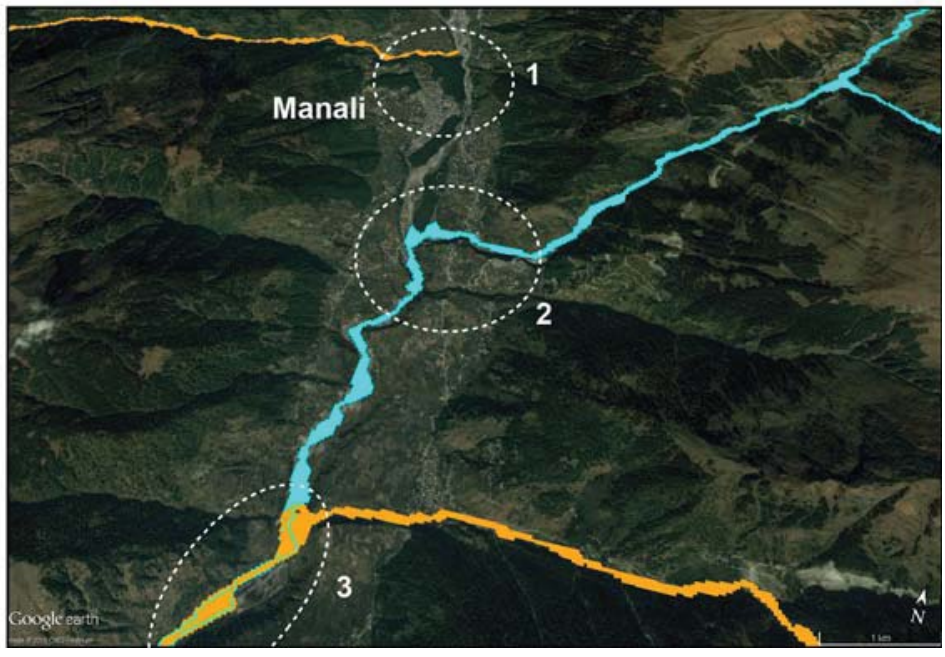

Fig. 9 a Overview of habitations, roads and major trekking tracks, and agricultural land in the Kullu and Parvati valleys exposed to current and potential new GLOF paths. b Google Earth perspective of the upper Kullu Valley, where GLOF paths threaten land areas adjacent to the Beas River. Situations 1-3 are discussed in the text

response strategies. Even if the anticipated new threats from glacial lakes do not eventuate, any such risk reduction measures implemented now would be worthwhile, strengthening local capacities and engaging the community directly within the adaptation process. In locations where the formation of new lakes over the coming decades creates an entirely new threat, local authorities would be encouraged to consider long timescales in their 
Fig. 10 Quantification of a human habitations, b road infrastructure, and $\mathbf{c}$ agricultural land areas exposed to GLOF hazard in Kullu District under both current (filled) and future (dashed) conditions. The colours relate to the current GLOF risk level assessed in Sect. 3 (see also Fig. 4). Human habitations and roads have been digitised directly from Indian topographic maps, while the agricultural land areas are extracted from the land cover data of the Indian National Remote Sensing Centre (a)

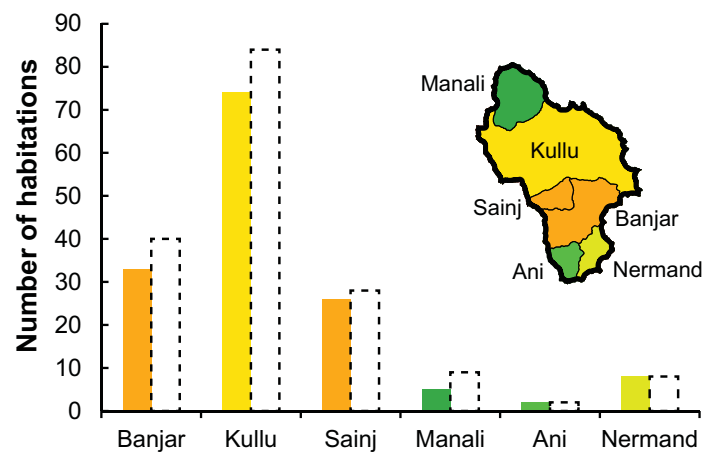

(b)

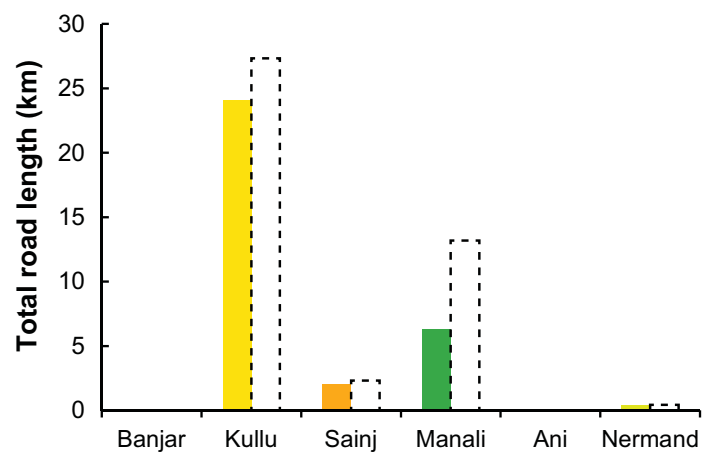

(c)

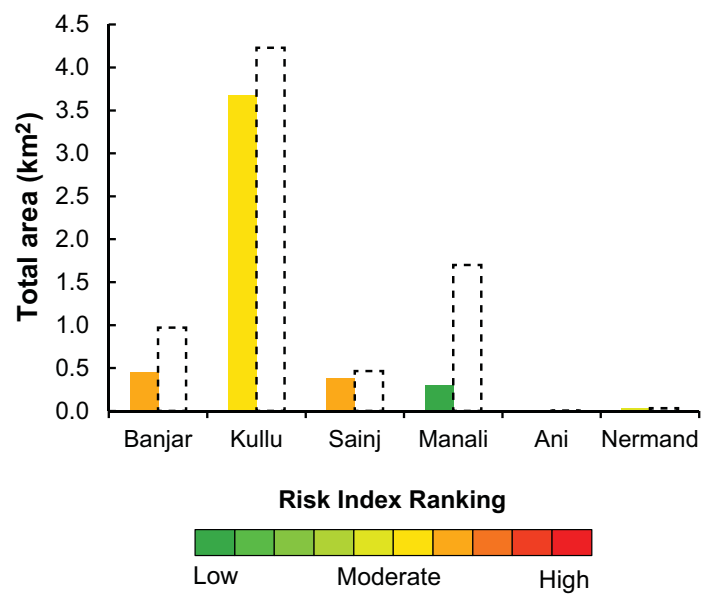

climate adaptation planning. This is particularly relevant for new infrastructural developments (residential property, roading, hydropower dams, etc.) where new threats could emerge during the intended lifetime of any constructions. 


\section{Conclusions}

The results of this study provide a scientific basis for prioritising state adaptation strategies towards those Districts or Tehsils across Himachal Pradesh currently facing the greatest risk from GLOFs, while providing a view towards future emerging threats. By adopting a climate risk perspective, we highlight the interacting physical and social determinants that can lead to a GLOF disaster and align our study with latest concepts used in international climate policy discussions. Transferring the methodological approach developed for Himachal Pradesh would enable a robust and objective GLOF hazard and risk assessment to be implemented across all Indian Himalayan states, and potentially beyond. However, a full range of triggering processes could be integrated, in particular considering the likely prominent role of hydrometeorological triggering in wetter, monsoon-dominated regions of the Himalaya. As illustrated in this study, GLOF events can travel large distances, across district, state, and even national administrative boundaries. Hence, a consistent methodological approach to identify the risk and anticipate emerging challenges is required for the Himalayan region. Reducing the current GLOF risk through early warning systems, increasing community awareness and preparedness, and sustainable land use planning would be a significant first step towards adapting to future challenges in many instances.

Acknowledgments This study was implemented within the Indian Himalayas Climate Adaptation Programme (IHCAP; www.ihcap.in), a project under the Global Programme Climate Change (GPCC) of the Swiss Agency for Development and Cooperation (SDC) in cooperation with the Department of Science and Technology, Government of India, and with support from the Government of Himachal Pradesh. The manuscript benefited from thoughtful comments provided by two anonymous reviewers.

\section{References}

Allen SK, Schneider D, Owens IF (2009) First approaches towards modelling glacial hazards in the Mount Cook region of New Zealand's Southern Alps. Nat Hazards Earth Syst Sci 9:481-499

Allen SK, Cox SC, Owens IF (2011) Rock avalanches and other landslides in the central Southern Alps of New Zealand: a regional study considering potential climate change impacts. Landslides 8:33-48

Allen SK, Rastner P, Arora M, Huggel C, Stoffel M (2015) Lake outburst and debris flow disaster at Kedarnath, June 2013: hydrometeorological triggering and topographic predisposition. Landslides. doi:10.1007/s10346-015-0584-3

Allen SK, Fiddes J, Linsbauer A, Randhawa SS, Saklani B, Salzmann N (2016) Permafrost studies in Kullu District, Himachal Pradesh. Curr Sci 11:257-260

Anacona PI, Mackintosh A, Norton KP (2014) Hazardous processes and events from glacier and permafrost areas: lessons from the Chilean and Argentinean Andes. Earth Surf Proc Landf. doi:10.1002/esp.3524

Bhutiyani MR, Kale VS, Pawar NJ (2007) Long-term trends in maximum, minimum and mean annual air temperatures across the Northwestern Himalaya during the twentieth century. Clim Change 85:159-177

Birkmann J (2014) Data, indicators and criteria for measuring vulnerability: theoretical bases and requirements. In: Birkmann J (ed) Measuring vulnerability to natural hazards: towards disaster resilient societies. United Nations University Press, Tokyo, pp 55-57

Bolch T, Buchroithner MF, Peters J, Baessler M, Bajracharya S (2008) Identification of glacier motion and potentially dangerous glacial lakes in the Mt. Everest region/Nepal using spaceborne imagery. Nat Hazards Earth Syst Sci 8:1329-1340

Bolch T, Peters J, Yegorov A, Pradhan B, Buchroithner M, Blagoveshchensky V (2011) Identification of potentially dangerous glacial lakes in the northern Tien Shan. Nat Hazards 59:1691-1714

Bolch T, Kulkarni A, Kaab A, Huggel C, Paul F, Cogley JG, Frey H, Kargel JS, Fujita K, Scheel M, Bajracharya S, Stoffel M (2012) The state and fate of Himalayan glaciers. Science 336:310-314

Braithwaite R, Raper S (2009) Estimating equilibrium-line altitude (ELA) from glacier inventory data. Ann Glaciol 50:127-132 
Carey M, Huggel C, Bury J, Portocarrero C, Haeberli W (2012) An integrated socio-environmental framework for glacier hazard management and climate change adaptation: lessons from Lake 513, Cordillera Blanca, Peru. Clim Change 112:733-767

Chen W, Cutter SL, Emrich CT, Shi P (2013) Measuring social vulnerability to natural hazards in the Yangtze river delta region, China. Int J Disaster Risk Sci 4:169-181

Church JA, Clark PU, Cazenave A, Gregory JM, Jevrejeva S, Levermann A, Merrifield MA, Milne GA, Nerem RS, Nunn PD, Payne AJ, Pfeffer WT, Stammer D, Unnikrishnan AS (2013) Sea level change. In: Stocker TF et al (eds) Climate change 2013: the physical science basis. contribution of working group I to the fifth assessment report of the Intergovernmental Panel on Climate Change. Cambridge University Press, Cambridge, pp 1137-1216

Clague JJ, Evans SG (1994) Formation and failure of natural dams in the Canadian Cordillera. Geol Surv Can Bull 464. doi:10.4095/194028

Clague JJ, Evans SG (2000) A review of catastrophic drainage of moraine-dammed lakes in British Columbia. Quat Sci Rev 19:1763-1783

Clague JJ, O'Connor JE (2014) Glacier-related outburst floods. In: Haeberli W, Whiteman C (eds) Snow and ice-related hazards, risks, and disasters. Elsevier, Amsterdam

Cogley JG (2011) Present and future states of Himalaya and Karakoram glaciers. Ann Glaciol 52:69-73

Cutter SL, Finch C (2008) Temporal and spatial changes in social vulnerability to natural hazards. Proc Natl Acad Sci 105:2301-2306

Cutter SL, Boruff BJ, Lynn Shirley W (2003) Social vulnerability to environmental hazards. Soc Sci Quart 84:242-261

Deline P, Gruber S, Delaloye R, Fischer L, Geertsema M, Giardino M, Hasler A, Kirkbride M, Krautblatter M, Magnin F, McColl S, Ravanel L, Schoeneich P (2014) Ice loss and slope stability in high-mountain regions. In: Haeberli W, Whiteman C (eds) Snow and ice-related hazards, risks, and disasters. Elsevier, Saint Louis

DoE S\&T (2012) State strategy and action plan on climate change, Himachal Pradesh, 2012. Department of Environment, Science \& Technology, Government of Himachal Pradesh, Shimla

Emmer A, Cochachin A (2013) The causes and mechanisms of moraine-dammed lake failures in the Cordillera Blanca, North American Cordillera, and Himalayas. AUC Geogr 48:5-15

Fischer L, Purves RS, Huggel C, Noetzli J, Haeberli W (2012) On the influence of topographic, geological and cryospheric factors on rock avalanches and rockfalls in high-mountain areas. Nat Hazards Earth Syst Sci 12:241-254

Frey H, Haeberli W, Linsbauer A, Huggel C, Paul F (2010) A multi-level strategy for anticipating future glacier lake formation and associated hazard potentials. Nat Hazards Earth Syst Sci 10:339-352

Frey H, Paul F, Strozzi T (2012) Compilation of a glacier inventory for the western Himalayas from satellite data: methods, challenges, and results. Remote Sens Environ 124:832-843

Frey H, Machguth H, Huss M, Huggel C, Bajracharya S, Bolch T, Kulkarni A, Linsbauer A, Salzmann N, Stoffel M (2014) Estimating the volume of glaciers in the Himalayan-Karakoram region using different methods. The Cryosphere 8:2313-2333

Fujita K, Sakai A, Takenaka S, Nuimura T, Surazakov AB, Sawagaki T, Yamanokuchi T (2013) Potential flood volume of Himalayan glacial lakes. Nat Hazards Earth Syst Sci 13:1827-1839

Government of Himachal Pradesh (2012) Himachal Pradesh state disaster management plan. Disaster Management Cell, Department of Revenue, Shimla

Gupta V, Sah MP (2008) Impact of the Trans-Himalayan Landslide Lake Outburst Flood (LLOF) in the Satluj catchment, Himachal Pradesh, India. Nat Hazards 45:379-390

Haeberli W (1983) Frequency and characteristics of glacier floods in the Swiss Alps. Ann Glaciol 4:85-90

Haeberli W, Hohmann R (2008) Climate, glaciers and permafrost in the Swiss Alps 2050: scenarios, consequences and recommendations. In: Kane DL, Hinkel KM (eds) Ninth international conference on permafrost. Institute of Northern Engineering, Fairbanks

Haeberli W, Kääb A, Mühll DV, Teysseire P (2001) Prevention of outburst floods from periglacial lakes at the Gruben Glacier, Valais, Swiss Alps. J Glaciol 47:111-122

Hegglin E, Huggel C (2008) An integrated assessment of vulnerability to glacial hazards: a case study in the Cordillera Blanca, Peru. Mt Res Dev 28:299-309

HPCCC (2014) A technical report on the inventory of moraine dammed glacial lakes (GLOFs) in Satluj, Beas, Chenab and Ravi Basins in Himachal Pradesh using IRS LISS III satellite data (2013). Himachal Pradesh State Center on Climate Change, State Council for Science Technology \& Environment

Huggel C, Kääb A, Haeberli W, Teysseire P, Paul F (2002) Remote sensing based assessment of hazards from glacier lake outbursts: a case study in the Swiss Alps. Can Geotech J 39:316-330 
Huggel C, Kääb A, Haeberli W, Krummenacher B (2003) Regional-scale GIS-models for assessments of hazards from glacier lake outbursts: evaluation and application in the Swiss Alps. Nat Hazards Earth Syst Sci 3:647-662

Huggel C, Haeberli W, Kääb A, Bieri D, Richardson S (2004) An assessment procedure for glacial hazards in the Swiss Alps. Can Geotech J 41:1068-1083

Huggel C, Zgraggen-Oswald S, Haeberli W, Kääb A, Polkvoj A, Galushkin I, Evans SG (2005) The 2002 rock/ice avalanche at Kolka/Karmadon, Russian Caucasus: assessment of extraordinary avalanche formation and mobility and application of QuickBird satellite imagery. Nat Hazards Earth Syst Sci 5:173-187

ICIMOD (2011) Glacial lakes and glacial lake outburst floods in Nepal. International Centre for Integrated Mountain Development (ICIMOD), Kathmandu

IPCC (2012) Managing the risks of extreme events and disasters to advance climate change adaptation. In: Field CB et al (eds) A special report of working groups I and II of the Intergovernmental Panel on Climate Change. Cambridge University Press, New York, p 582

IPCC (2014) Climate change 2014: impacts, adaptation, and vulnerability. Part A: global and sectoral aspects. In: Field CB et al (eds) Contribution of working group II to the fifth assessment report of the Intergovernmental Panel on Climate Change. Cambridge University Press, Cambridge, New York, p 1132

Ives JD, Shrestha RB, Mool PK (2010) Formation of glacial lakes in the Hindu Kush-Himalayas and GLOF risk assessment. ICIMOD, Kathmandu

Kääb A, Reynolds JM, Haeberli W (2005) Glacier and permafrost hazards in high mountains. In: Huber UM, Bugmann HKM, Reasoner MA (eds) Global change and mountain regions. An overview of current knowledge. Springer, Dordrecht, pp 225-234

Khanal NR, Mool PK, Shrestha AB, Rasul G, Ghimire PK, Shrestha RB, Joshi SP (2015) A comprehensive approach and methods for glacial lake outburst flood risk assessment, with examples from Nepal and the transboundary area. Int J Water Resour Dev 31:219-237

Korup O, Tweed F (2007) Ice, moraine, and landslide dams in mountainous terrain. Quart Sci Rev 26:3406-3422

Kulkarni AV, Karyakarte Y (2014) Observed changes in Himalayan glaciers. Curr Sci 106:237-244

Lal PN, Mitchell T, Aldunce P, Auld H, Mechler R, Miyan A, Romano LE, Zakaria S (2012) National systems for managing the risks from climate extremes and disasters. In: Field CB et al (eds) Managing the risks of extreme events and disasters to advance climate change adaptation. A special report of working groups I and II of the Intergovernmental Panel on Climate Change (IPCC). Cambridge University Press, Cambridge, pp 339-392

Linsbauer A, Paul F, Haeberli W (2012) Modeling glacier thickness distribution and bed topography over entire mountain ranges with GlabTop: application of a fast and robust approach. J Geophys Res. doi:10.1029/2011JF002313

Linsbauer A, Frey H, Haeberli W, Machguth H, Azam MF, Allen S (2016) Modelling glacier-bed overdeepenings and possible future lakes for the glaciers in the Himalaya-Karakoram region. Ann Glaciol 57:119-130

Liu J-J, Tang C, Cheng Z-L (2013) The two main mechanisms of Glacier Lake Outburst Flood in Tibet, China. J Mt Sci 10:239-248

Lliboutry L, Morales AB, Pautre A, Schneider B (1977) Glaciological problems set by the control of dangerous lakes in Cordillera Blanca, Peru. I. Historic failure of morainic dams, their causes and prevention. J Glaciol 18:239-254

McKillop RJ, Clague JJ (2007) A procedure for making objective preliminary assessments of outburst flood hazard from moraine-dammed lakes in southwestern British Colombia. Nat Hazards 41:131-157

Noetzli J, Hoelzle M, Haeberli W (2003) Mountain permafrost and recent Alpine rock-fall events: a GISbased approach to determine critical factors. In: Phillips M, Springman SM, Arenson LU (eds) PERMAFROST, Proceedings of the eighth international conference on permafrost. Swets \& Zeitlinger, Zurich, pp 827-832

O'Callaghan JF (1984) The extraction of drainage networks from digital elevation data. Comput Vis Graph Image Process 28:323-344

O'Connor JE, Hardison JH, Costa JE (2001) Debris flows from failures of Neoglacial-Age moraine dams in the Three Sisters and Mount Jefferson wilderness areas. Oregon, US Geological Survey Professional Paper 1606

Paul F, Linsbauer A (2012) Modeling of glacier bed topography from glacier outlines, central branch lines, and a DEM. Int J Geogr Inf Sci 26:1173-1190

Randhawa SS, Sood RK, Rathore BP, Kulkarni AV (2005) Moraine-dammed lakes study in the Chenab and the Satluj river basins using IRS data. J Indian Soc Remote Sens 33:285-290 
Reynolds JM (1992) The identification and mitigation of glacier-related hazards: examples from the Cordillera Blanca, Peru. In: McCall GJH, Laming DJC, Scott SC (eds) Geohazards natural and man-made. Chapman and Hall, London, pp 143-157

Richardson SD, Reynolds JM (2000) An overview of glacial hazards in the Himalayas. Quat Int 65(66):31-47

Romstad B, Harbitz C, Domaas U (2009) A GIS method for assessment of rock slide tsunami hazard in all Norwegion lakes and reservoirs. Nat Hazards Earth Syst Sci 9:353-364

Ruiz-Villanueva V, Allen S, Arora M, Goel NK, Stoffel M (2016) Recent catastrophic landslide lake outburst floods in the Himalayan Mountain Range. Prog Phys Geogr. doi:10.1177/0309133316658614

Schaub Y (2015) Outburst floods from high-mountain lakes: risk analysis of cascading processes under present and future conditions. PhD thesis, Department of Geography, University of Zurich, Switzerland

Schaub Y, Haeberli W, Huggel C, Künzler M, Bründl M (2013) Landslides and new lakes in deglaciating areas: a risk management framework. In: Margottini C, Canuti P, Sassa K (eds) Landslide science and practice. Springer, Heidelberg, pp 31-38

Singh D, Horton DE, Tsiang M, Haugen M, Ashfaq M, Mei R, Rastogi D, Johnson NC, Charland A, Rajaratnam B, Diffenbaugh NS (2014) Severe precipitation in Northern India in June 2013: causes, historical context, and changes in probability. In: Herring SC, Hoerling MP, Peterson TC, Stott PA (eds) Explaining extreme events of 2013 from a climate perspective. Bulletin of the American Meteorological Society, vol 95, no 9, September 2014. American Meteorological Society

Vuichard D, Zimmermann M (1987) The 1985 catastrophic drainage of a moraine-dammed lake, Khumbu Himal, Nepal: causes and consequences. Mt Res Dev 7:91-110

Wang W, Yao T, Gao Y, Yang X, Kattel DB (2011) A first-order method to identify potentially dangerous glacial lakes in a region of the southeastern Tibetan Plateau. Mt Res Dev 31:122-130

Wang S, Dahe Q, Xiao C (2015) Moraine-dammed lake distribution and outburst flood risk in the Chinese Himalaya. J Glaciol 61:115-126

Wessels R, Kargel JS, Kieffer HH (2002) ASTER measurement of supraglacial lakes in the Mount Everest region of the Himalaya. Ann Glaciol 34:399-408

Worni R, Stoffel M, Huggel C, Volz C, Casteller A, Luckman B (2012) Analysis and dynamic modeling of a moraine failure and glacier lake outburst flood at Ventisquero Negro, Patagonian Andes (Argentina). J Hydrol 444-445:134-145

Worni R, Huggel C, Stoffel M (2013) Glacier lakes in the Indian Himalayas: from an area-wide glacial lake inventory to on-site and modeling based risk assessment of critical glacial lakes. Sci Total Environ 468-469:s71-s84

Worni R, Huggel C, Clague JJ, Schaub Y, Stoffel M (2014) Coupling glacial lake impact, dam breach, and flood processes: a modeling perspective. Geomorphology 224:161-176 